\title{
Cold hardiness and effect of winter chilling on mortality of passionvine hopper (Scolypopa australis) eggs
}

\author{
D.P. Logan ${ }^{1}$, C.A. Rowe ${ }^{2}$ and P.G. Connolly ${ }^{1}$ \\ ${ }^{1}$ The New Zealand Institute for Plant \& Food Research Limited, Private Bag 92169, Auckland \\ 1142, New Zealand \\ ${ }^{2}$ The New Zealand Institute for Plant \& Food Research Ltd, 412 No. 1 Road, RD2, Te Puke \\ 3182, New Zealand \\ Corresponding author: david.logan@plantandfood.co.nz
}

\begin{abstract}
Passionvine hopper (PVH; Scolypopa australis) is a significant production pest of kiwifruit in New Zealand and an occasional pest of some other crops. It is also associated with toxic honey. Estimated losses of kiwifruit due to sooty mould associated with feeding by $\mathrm{PVH}$ varies from c. $0.5-3 \%$ of Class- 1 fruit packed, depending on year. Mortality of overwintering eggs due to winter chill may contribute to this inter-annual variation. After cold-hardening under ambient winter conditions, eggs were exposed to six temperatures between $-11^{\circ} \mathrm{C}$ and $0^{\circ} \mathrm{C}$. The median minimum lethal temperatures for a 1 -h exposure was $-9.1^{\circ} \mathrm{C}$. Longer exposures (up to $24 \mathrm{~h}$ ) did not strongly influence mortality at different sub-zero temperatures. Mortality of eggs held at a range of North Island sites was most strongly correlated with the sum of chilling hour degrees (CHD) below a threshold of $10^{\circ} \mathrm{C}$ in August $(r=0.89)$.
\end{abstract}

Keywords Scolypopa australis, kiwifruit, winter, mortality.

\section{INTRODUCTION}

Passionvine hopper (PVH), Scolypopa australis (Walker) (Hemiptera: Ricaniidae), is a significant production pest of kiwifruit in New Zealand and is also associated with toxic honey (Robertson et al. 2010). Its native range is the coastal areas of south-east Australia and it has been present in New Zealand since the late 1800s (Riley \& Howard 1891). Passionvine hopper has a oneyear life cycle with nymphs hatching in late spring and adults present from summer until early winter (Cumber 1966). Adults and nymphs tend to aggregate on the actively growing shoots of a wide variety of plant species (Spiller \& Wise 1982, Logan et al. 2002) where they feed on phloem sap. Eggs are inserted shallowly into dying and dead plant material, as well as structures built of wood, between January and June.

In kiwifruit, feeding by nymphs and particularly adults is associated with the development of sooty moulds on fruit, which makes them unsuitable for export markets. The estimated seasonal loss due to sooty mould is c. $\leq 0.5 \%$ of Class -1 fruit packed; however, in some seasons losses may be c. 2-3\% with minimum annual costs to the industry of NZ\$15-20M (Shane Max, pers. comm., 2010). Annual variability of PVH numbers is one factor that may influence inter-annual variation in fruit loss due to sooty mould. Populations of PVH tend to be higher in areas adjacent to kiwifruit orchards, such as areas of weedy regrowth or home gardens, than on kiwifruit crops (Steven 1990) and effective control within orchard blocks is negated 
by immigrating adults. Hence it is important to measure mortality factors in non-crop areas that may influence PVH populations. The best-studied natural PVH mortality factor is egg parasitism, which can be substantial (up to 87\%) but has not prevented pest problems in kiwifruit production areas (Cumber 1966; Gerard 1985; Charles \& Allan 2004). Climate and weather events can be important drivers of insect population dynamics in general (Andrewartha \& Birch 1984; Chown \& Gaston 1999) and, according to Charles \& Allan (2004), large seasonal variation in PVH numbers may also be induced by seasonal weather patterns. Passionvine hoppers overwinter as eggs and need to survive frosts in most kiwifruit production areas. The absence of PVH from much of the North Island volcanic plateau and from the South Island (except for the coastal margins of the northern quarter) is consistent with a hypothesis that cool weather, either as severe chill events or as an accumulation of cold, is associated with egg mortality.

Our objectives were to assess the mortality of PVH eggs following exposure to relatively brief periods of cold shock at temperatures $\leq 0^{\circ} \mathrm{C}$ in laboratory tests and to actual winter temperatures experienced at a selection of 16 field sites in the North Island that differed in latitude and elevation. These two approaches were used as there may be different mortality responses to short-term chill associated with extreme events such as frosts and long-term exposure to winter temperatures (Bale 1996). The data will be important for assessing whether or not cold weather in kiwifruit-growing regions is associated with variation of losses to sooty mould through its effects on PVH eggs.

\section{MATERIALS AND METHODS}

\section{Extreme minimum air temperatures}

The major kiwifruit production area in New Zealand is around Te Puke in the Bay of Plenty region of the North Island. The southern-most area where kiwifruit are grown commercially is Nelson in the South Island. Therefore, the coldest air temperatures typical of these two areas were determined using minimum monthly dry-bulb air temperatures recorded between 2001 and 2016 at the Te Puke Research Orchard of Plant \& Food Research (TPRO) (37.8205S, 176.3175E, WGS84 ellipsoid) and Nelson aerodrome weather station (41.3008S, 173.2160E) (hortplus.metwatch.co.nz and cliflo.niwa.co.nz respectively, final access on 4 April 2017).

\section{Egg collection and mortality assessment}

Adult PVH were collected from various host plants at TPRO during early March 2012-2015 and were placed in cages with sticks of balsa wood (100 $\mathrm{mm} \times 5 \mathrm{~mm}$ ) as oviposition sites secured to potted mahoe plants (Melicytus ramiflorus). Eggs were laid during March and early April, and at least 120 balsa-wood sticks with $>100$ eggs each were placed in fine muslin bags to exclude egg parasitoids and predators. Bags were hung in a shaded area outdoors at TPRO before and after experiments (July-August for lab experiments or May-September for field surveys). Eggs were thus acclimated to Te Puke autumn and winter temperatures. Fruit stalks (approximately 50) heavily infested with PVH eggs were collected from orchard blocks of kiwifruit (Actinidia chinensis var. deliciosa 'Hayward') at TPRO for one experiment in 2015.

To determine mortality, eggs were dissected from balsa-wood sticks or kiwifruit stalks during the autumn following the year of the experiment. Assessment was delayed to allow hatching to be completed naturally and for any parasitoids to emerge. Hatched eggs were readily distinguished from dead eggs by having an empty hyaline chorion with a characteristic split (Cumber 1967). Parasitised eggs were separated from dead or hatched eggs by the round hole created by the escaping parasitoid (Cumber 1967). There were some parasitised eggs in most samples but the rate was generally less than 5\% (range 0.4-9.9\%) and these eggs were excluded from counts of dead eggs.

\section{Laboratory experiments}

Cool-store: The effect of $0^{\circ} \mathrm{C}$ at durations of 1,2 , $4,7,10,14,17,21$ and 24 days on the mortality of PVH eggs in balsa wood sticks was determined in a cool store unit during July and August 
2012. The temperature was controlled to $0^{\circ} \mathrm{C}$ by a commercial calibrated monitoring system accurate to $0.5^{\circ} \mathrm{C}$.

Water bath: Four subsequent experiments were carried out using three refrigerated water baths filled with a 50\% antifreeze solution (PEG6000). Eggs within balsa wood sticks or fruit stalks were inserted into an aluminium tube with base sealed (120-mm high, 20-mm wide, inner wall thickness $0.5 \mathrm{~mm})$. The tube was then plugged at the top and held immersed in the antifreeze solution with the aid of a retort stand. In Water-bath Experiment 1, ten replicate balsa wood sticks (average 172 eggs; range 77-227) were used to examine the effect of two 1-h exposures compared with a single 1-h exposure at each of six constant sub-zero temperatures $\left(-1,-3,-5,-7,-9\right.$ and $\left.-11^{\circ} \mathrm{C}\right)$. The second 1-h exposure was given $14 \mathrm{~d}$ after the first. During the interval eggs were kept at ambient winter temperatures (range of approximately -2 to $18^{\circ} \mathrm{C}$ ). A 1 -h period was selected to represent a natural period of extreme chilling. In Waterbath Experiment 2, the median lethal temperature $\left(\mathrm{LT}_{50}\right)$ was estimated using 20 replicate balsa wood sticks (average 183 eggs, range 69-298) exposed at each of six sub-zero temperatures (nominally -1 , $-3,-5,-7,-9$ and $\left.-11^{\circ} \mathrm{C}\right)$. In Water-bath Experiment 3 , the effect of substrate (balsa wood stick or kiwifruit fruit stalk) on the response of eggs to three sub-zero temperatures (nominally -1, -5 and $-9^{\circ} \mathrm{C}$ ) for $6 \mathrm{~h}$ was determined. There were ten replicates for each treatment and an average of 128 eggs (range 51-170) in balsa wood sticks and 48 eggs (range 8-86) in fruit stalks. In Waterbath Experiment 4, the interaction of temperature and exposure period on mortality of eggs in balsa wood sticks (average 127 eggs, range 51-212) was re-examined for combinations of three sub-zero temperatures (nominally $-1,-5$ and $-9^{\circ} \mathrm{C}$ ) and three exposure periods (1, 6 and $24 \mathrm{~h}$ ). There were ten replicates for each treatment.

Cool-store and water-bath experiments were carried out from mid-July to mid-August 201215. Delaying the experiments until late winter allowed natural cold-hardiness to develop. As there was an insufficient number of water baths to run all temperatures at the same time, the order of treatments was randomised for each group of replicates. Temperatures were scanned at 1-min intervals with thermocouples (Type $\mathrm{T}$, copperconstantan) and recorded by a multi-channel data logger (Campbell CR10). All thermocouples were calibrated against a standard thermometer immediately prior to the experiments. To measure temperatures experienced by eggs in each water bath experiment, a thermocouple was attached to a balsa wood stick or fruit stalk containing PVH eggs.

\section{Statistical analyses for laboratory experiments}

A quasibinomial Generalised Linear Model (GLM) was used to establish the effect of storage time $(1-24 \mathrm{~h})$ at $0^{\circ} \mathrm{C}$ on egg mortality. The quasibinomial model adjusts for the over-dispersion of the data. A comparison of deviance for binomial GLMs was used to determine the effect of 1-h and 2-h exposures to sub-zero temperatures on egg mortality. To estimate an LT50, data were divided into four pseudo-replicates (Chambers \& Hastie 1992). Separate binomial GLMs were used to fit lines to mortality points at each of six temperatures. From each of these lines, the temperature corresponding to $50 \%$ mortality was estimated, and the geometric mean and 95\% CI calculated. The effect of substrate (balsa wood stick or kiwifruit fruit stalk) was estimated by comparing the deviance for GLMs fitted to egg mortality for each substrate. The interaction between three temperatures and three exposure periods was estimated by fitting a quasibinomial GLM since treating the variables as continuous would not have provided sufficient information to analyse meaningfully. All analyses were carried out in $\mathrm{R}$ version 3.3.2 (R Development Core Team 2016).

\section{Field mortality}

The effect of chilling during each of three winters (2011, 2012 and 2014) on the mortality of PVH eggs was estimated at a selection of 16 field sites in the North Island (2011: $\mathrm{n}=11 ; 2012, \mathrm{n}=11 ; 2014$ : $\mathrm{n}=5$ ) (Table 1, Figure 1). Sites were selected to include some where PVH adults and eggs had been observed in the vicinity in preceding summers, and some where PVH was thought to be absent. 
Table 1 Descriptions of the field sites used to determine cumulative effect of chilling on egg mortality. The minimum winter temperatures are from the temperature series recorded at each site by data logger between May and September.

\begin{tabular}{|c|c|c|c|c|c|}
\hline Site & $\begin{array}{c}\text { Latitude } \\
\text { (degrees south) }\end{array}$ & $\begin{array}{c}\text { Estimated } \\
\text { elevation (m a.s.l.) }\end{array}$ & $\begin{array}{l}\text { PVH known to exist } \\
\text { at this location }\end{array}$ & $\begin{array}{l}\text { Years } \\
\text { used }\end{array}$ & $\begin{array}{l}\text { Min. winter } \\
\text { temp. }\left({ }^{\circ} \mathrm{C}\right)\end{array}$ \\
\hline Maketu & 37.7721 & 5 & Yes & 2011 & -2.5 \\
\hline Te Puke1 (TPRO) & 37.8195 & 98 & Yes & 2011 & -2.1 \\
\hline \multirow[t]{3}{*}{ Te Puke2 (TPRO) } & \multirow[t]{3}{*}{37.8226} & \multirow[t]{3}{*}{98} & \multirow[t]{3}{*}{ Yes } & 2011 & -2.1 \\
\hline & & & & 2012 & -1.5 \\
\hline & & & & 2014 & -0.8 \\
\hline \multirow[t]{2}{*}{ Te Puke3 } & \multirow{2}{*}{37.8412} & \multirow{2}{*}{183} & \multirow{2}{*}{ Yes } & 2011 & -3.0 \\
\hline & & & & 2012 & -2.5 \\
\hline Kaimail & 37.8374 & 340 & No & 2012 & -0.4 \\
\hline Kaimai2 & 37.8672 & 489 & No & 2012 & -0.7 \\
\hline Kaimai3 & 37.8698 & 491 & No & 2014 & -0.3 \\
\hline \multirow[t]{2}{*}{ Rotorua1 } & \multirow[t]{2}{*}{38.1406} & \multirow[t]{2}{*}{300} & \multirow[t]{2}{*}{ Yes } & 2011 & -3.6 \\
\hline & & & & 2012 & -3.0 \\
\hline \multirow[t]{2}{*}{ Rotorua2 } & \multirow[t]{2}{*}{38.2055} & \multirow[t]{2}{*}{500} & \multirow[t]{2}{*}{ No } & 2011 & -1.9 \\
\hline & & & & 2012 & -0.7 \\
\hline Whangamomona & 39.1430 & 151 & Yes & 2011 & -2.1 \\
\hline \multirow[t]{2}{*}{ Taupo } & \multirow[t]{2}{*}{38.6743} & \multirow[t]{2}{*}{397} & \multirow[t]{2}{*}{ Yes } & 2011 & -3.5 \\
\hline & & & & 2012 & -3.3 \\
\hline \multirow[t]{2}{*}{ Tongariro } & \multirow[t]{2}{*}{39.0503} & \multirow[t]{2}{*}{709} & \multirow[t]{2}{*}{ No } & 2011 & -7.5 \\
\hline & & & & 2012 & -5.3 \\
\hline Raurimu & 39.1154 & 581 & No & 2014 & -3.8 \\
\hline \multirow[t]{2}{*}{ Ohakune } & \multirow[t]{2}{*}{39.3830} & \multirow[t]{2}{*}{627} & \multirow[t]{2}{*}{ No } & 2011 & -3.9 \\
\hline & & & & 2012 & -4.8 \\
\hline Raetihi & 39.4291 & 525 & No & 2014 & -4.5 \\
\hline \multirow[t]{3}{*}{ Waiouru } & 39.4619 & 814 & No & 2011 & -7.4 \\
\hline & & & & 2012 & -5.5 \\
\hline & & & & 2014 & -5.2 \\
\hline
\end{tabular}

Balsa wood sticks with PVH eggs were established at each location in early-mid May and removed in early October. At each site, a balsa wood stick with a total of c. 150 eggs was secured within a vertical section of PVC pipe $(100-\mathrm{mm}$ high, 40-mm diameter) to protect it from damage by wind or malentities. A Stevenson screen $\left(\right.$ DataMate $^{\mathrm{TM}}$ ) with datalogger (Tinytag Ultra 2 TGU-4017) was hung immediately below the PVC section. Both screen and PVC section were secured to a tree branch c. $0.5-1.5 \mathrm{~m}$ above the ground. Temperatures were recorded at 15 -min intervals.

Variables to quantify winter chilling were generated from the logger recordings. The variables were the coldest minimum temperature and the chilling hour-degrees accumulated below thresholds of $-4,-2,0,2,4,6,8$, and $10^{\circ} \mathrm{C}$ for winter (June, July and August) and for each separate winter month (36 variables). The largest threshold of $10^{\circ} \mathrm{C}$ was based on an estimate of the minimum threshold for egg development by Gerard (1985). The lowest threshold was based on the $80^{\text {th }}$ percentile of minimum monthly temperatures for all sites. Chilling hour degrees (CHD) were calculated from the temperatures recorded at each site. To increase the accuracy of the estimated $\mathrm{CHD}$, temperatures were linearly interpolated between recorded site temperatures 


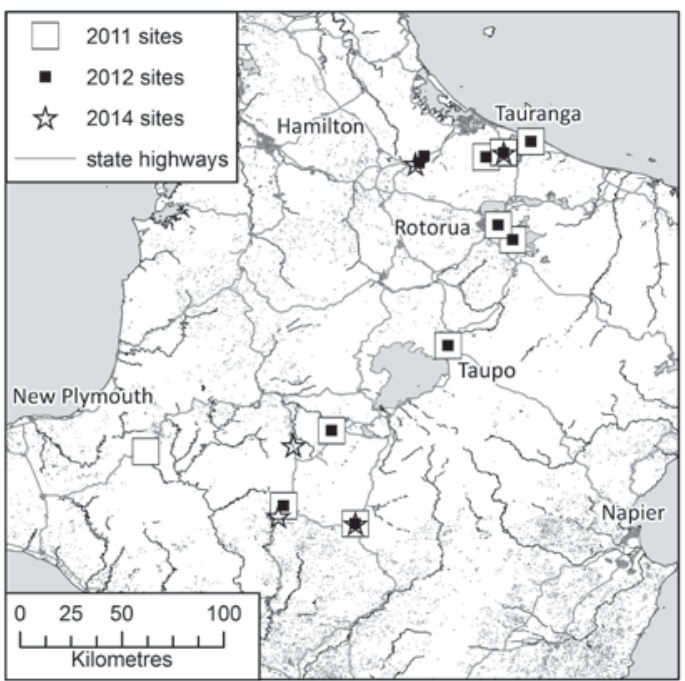

Figure 1 Location of field sites in the North Island used to estimate the cumulative effects of chilling on the mortality of passionvine hopper (PVH) eggs. At each site c. $150 \mathrm{PVH}$ eggs laid into balsa wood sticks at the Te Puke Research Orchard were exposed to local temperatures during May-September 2011, 2012 and 2014.

at 1-min intervals. A 1-min interval was used to avoid the accumulation of error when the threshold temperature occurred in the interval between consecutive recorded temperatures. The CHD for each of the months of June, July and August was estimated as the area of a series of rectangles each with a base of $1 \mathrm{~min}$ and a height calculated as the threshold temperature $\left(-4,-2,0,2,4,6,8\right.$, or $\left.10^{\circ} \mathrm{C}\right)$ minus the midpoint temperature for the rectangle, with negative areas ignored. The midpoint temperature was the average of two consecutive interpolated temperatures. Calculations began and ended at temperatures recorded closest to midnight at the start and the end of each month. There were 32 CHD sums (eight thresholds for June, July, August and winter) calculated for each of the 27 combinations of year and site. The strength of the association of each of the 32 CHD sums with the mortality of eggs for the 27 combinations of year and site was then estimated by correlation co-efficient. Similarly the strength of association of the coldest minimum temperatures for June, July, August and winter and egg mortality for each site and year combination was estimated by correlation co-efficient.

\section{RESULTS}

\section{Extreme minimum air temperatures}

The coldest annual temperature for TPRO was in the range -2.1 to $0.4^{\circ} \mathrm{C}$ and was recorded in July for half the out of 16 years studied and May, June, August or October for other years. The coldest annual temperature for the Nelson aerodrome was in the range -4.2 to $-1.1^{\circ} \mathrm{C}$ and was also usually recorded in July ( 9 out of 16 years) and June or August for other years.

\section{Laboratory experiments}

Cool-store: There was a slight tendency for mortality of PVH eggs to increase with storage time at constant $0^{\circ} \mathrm{C}$ (Figure 2). There were sufficient individuals to ascertain the mortality for each duration between 1 and 24 days (average 247 eggs, range 221-284) but the model predictions are less certain because of the over-dispersion of the data. Analysis of the deviances associated with the GLM indicate the fitted line could be observed under the null

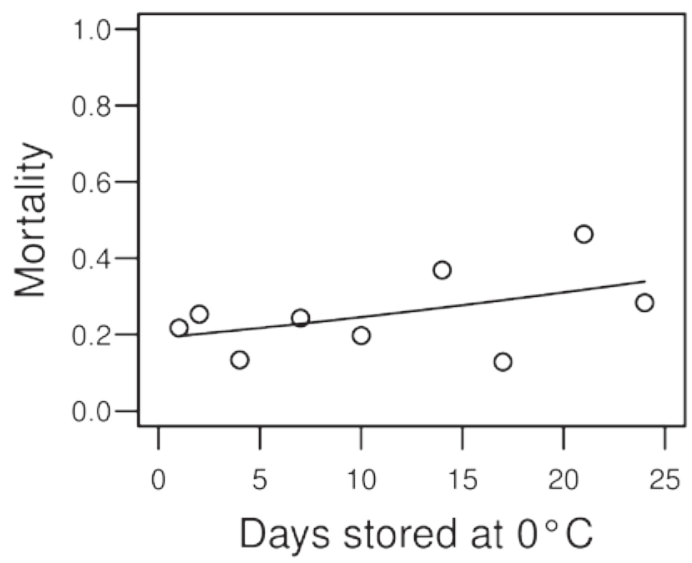

Figure 2 Effect of number of days of storage at $0^{\circ} \mathrm{C}$ on the mortality of passionvine hopper eggs in balsawood sticks and a fitted model. 
hypothesis of no influence with a probability of $0.145\left(\chi^{2}=2.12, \mathrm{df}=7\right)$. The dispersion parameter for the quasibinomial family was estimated at 12.9.

Water bath: In Water-bath Experiment 1, higher mortality of PVH eggs occurred at lower temperatures in the range tested (mean temperature per minute measured by thermocouples: $-11.31,-9.33,-7.54,-5.63,-2.73$, $-0.88^{\circ} \mathrm{C}$ ) (Figure 3 ). However mortality of eggs after two 1-h exposures was less than that for a single 1 - $\mathrm{h}$ exposure $\left(\chi^{2}=4.27, \mathrm{df}=1, \mathrm{P}=0.039\right.$, dispersion parameter $=29.6)$.

In Water-bath Experiment 2, median lethal temperatures $\left(\mathrm{LT}_{50}\right)$ for four pseudo-replicates of PVH eggs exposed to temperatures between -0.8 and $-11.0^{\circ} \mathrm{C}$ for $1 \mathrm{~h}$ were $-7.9,-9.6,-9.5$ and $-9.2^{\circ} \mathrm{C}$. The geometric mean of the four estimates was $-9.1^{\circ} \mathrm{C}$ with a $95 \% \mathrm{CI}$ of -10.4 to $-7.8^{\circ} \mathrm{C}$.

In Water-bath Experiment 3, mortality due to sub-zero temperatures was generally lower for eggs laid on kiwifruit fruit stalks than for eggs laid on balsa wood sticks $\left(\chi^{2}=5.1, \mathrm{df}=1\right.$, $\mathrm{P}=0.024$, dispersion parameter $=11.3)($ Table 2$)$ when based on a comparison of the deviance for GLMs. The difference was minimal at the coldest temperature $\left(-8.7^{\circ} \mathrm{C}\right)$.

In Water-bath Experiment 4, the effect of exposure period ( $1 \mathrm{~h}, 6 \mathrm{~h}$, and $24 \mathrm{~h}$ ) was not consistent for different temperatures $(-8.7,-4.5$, and $-1{ }^{\circ} \mathrm{C}$ ) and was estimated to be less than $1 \%$ likely under the null hypothesis of chance effects $\left(\chi^{2}=13.4, \mathrm{df}=1, \mathrm{P}=0.0095\right.$, dispersion parameter $=10.6)$ (Table 3 ).

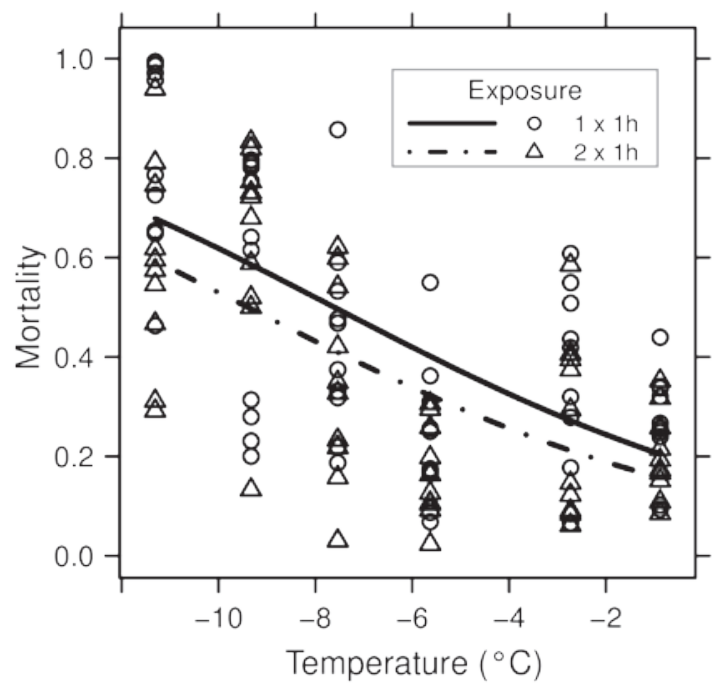

Figure 3 Effect of one 1-h (o) or two 1-h $(\Delta)$ exposures on mortality of passionvine hopper eggs at sub-zero temperatures $(-11.31,-9.33$, $-7.54,-5.63,-2.73$, and $\left.-0.88^{\circ} \mathrm{C}\right)$. Solid ( $1-\mathrm{h}$ exposure) and dashed (two 1-h exposures) lines are mortalities predicted by GLMs.

Table 2 Predicted mortalities and 95\% CI for passionvine hopper eggs laid in two different substrates (balsa wood sticks, kiwifruit fruit stalks) and exposed to sub-zero temperatures for $1 \mathrm{~h}$. Predictions were from GLMs of egg mortality fitted to temperature.

\begin{tabular}{lcccc}
\hline Substrate & $\begin{array}{c}\text { Temperature } \\
\left({ }^{\circ} \mathrm{C}\right)\end{array}$ & $\begin{array}{c}\text { Lower limit of } \\
95 \% \text { CI }\end{array}$ & Mean \% mortality & $\begin{array}{c}\text { Upper limit of } \\
95 \% \text { CI }\end{array}$ \\
\hline Balsa wood & -8.7 & 54 & 65 & 74 \\
Fruit stalk & -8.7 & 47 & 65 & 79 \\
Balsa wood & -4.5 & 34 & 44 & 54 \\
Fruit stalk & -4.5 & 18 & 33 & 52 \\
Balsa wood & -1 & 34 & 44 & 55 \\
Fruit stalk & -1 & 12 & 22 & 38 \\
\hline
\end{tabular}


Table 3 Predicted mortalities and 95\% CI for passionvine hopper eggs exposed to sub-zero temperatures $\left(-1,-4.5\right.$ or $\left.-8.7^{\circ} \mathrm{C}\right)$ for $1-\mathrm{h}, 6-\mathrm{h}$ or $24-\mathrm{h}$ periods. Predictions were from a quasibinomial GLMs of egg mortality fitted to temperature and exposure period.

\begin{tabular}{ccccc}
\hline $\begin{array}{c}\text { Exposure } \\
(\mathrm{h})\end{array}$ & $\begin{array}{c}\text { Temperature } \\
\left({ }^{\circ} \mathrm{C}\right)\end{array}$ & $\begin{array}{c}\text { Lower limit of 95\% } \\
\text { CI }\end{array}$ & $\begin{array}{c}\text { Mean \% } \\
\text { mortality }\end{array}$ & $\begin{array}{c}\text { Upper limit of } \\
\text { 95\% CI }\end{array}$ \\
\hline 1 & -8.7 & 74 & 83 & 90 \\
6 & -8.7 & 54 & 65 & 74 \\
24 & -8.7 & 52 & 62 & 72 \\
1 & -4.5 & 30 & 40 & 51 \\
6 & -4.5 & 34 & 44 & 54 \\
24 & -4.5 & 30 & 39 & 49 \\
1 & -1 & 28 & 38 & 48 \\
6 & -1 & 34 & 44 & 54 \\
24 & -1 & 27 & 36 & 47 \\
\hline
\end{tabular}

\section{Field mortality}

The mortality of eggs exposed to winters (2011, 2012 and 2014) at different locations in the North Island ranged from 6 to 100\% (Table 4). Correlation co-efficients for the association of egg mortality with lowest recorded minimum temperatures in winter (June, July and August) and June, July and August separately were -0.69 , $-0.36,-0.62$ and -0.48 respectively indicating weak relationships (Figure 4). The strongest associations $(r=0.87-0.89)$ between CHD sums and egg mortality was when the highest thresholds $\left(4,6,8\right.$ and $\left.10^{\circ} \mathrm{C}\right)$ were applied to August temperatures pooled for all three years (Figure 4). The weakest associations were between egg mortality and CHDs for June pooled for all three years $(r=0.09-0.25)$ and in general for the lowest thresholds.

Table 4 Mortality of passionvine hopper eggs in balsa wood sticks exposed at different sites in the North Island during May-September 2011, 2012 and 2014.

\begin{tabular}{lccc}
\hline & & Per cent & mortality (number of eggs) \\
Site & 2011 & 2012 & 2014 \\
\hline Maketu & $36.6(281)$ & $20.7(222)$ & - \\
Te Puke1 (TPRO) & $27.9(365)$ & $25.8(333)$ & $6.0(100)$ \\
Te Puke2 (TPRO) & $8.4(308)$ & - & - \\
Te Puke3 & $25.6(320)$ & $23.3(257)$ & - \\
Kaimai1 & - & $33.8(284)$ & - \\
Kaimai2 & - & $22.5(333)$ & $51.9(108)$ \\
Kaimai3 & - & - & - \\
Rotorua1 & $38.9(267)$ & $33.3(219)$ & - \\
Rotorua2 & $21.0(281)$ & $28.6(262)$ & - \\
Whangamomona & $9.2(248)$ & - & - \\
Taupo & $57.6(380)$ & $34.9(278)$ & - \\
Tongariro & $100(369)$ & $32.2(248)$ & $90.9(121)$ \\
Raurimu & - & - & - \\
Ohakune & $85.4(309)$ & $13.1(274)$ & $77.2(101)$ \\
Raetihi & - & - & $100(100)$ \\
Waiouru & $100(331)$ & $61.9(444)$ & \\
\hline
\end{tabular}



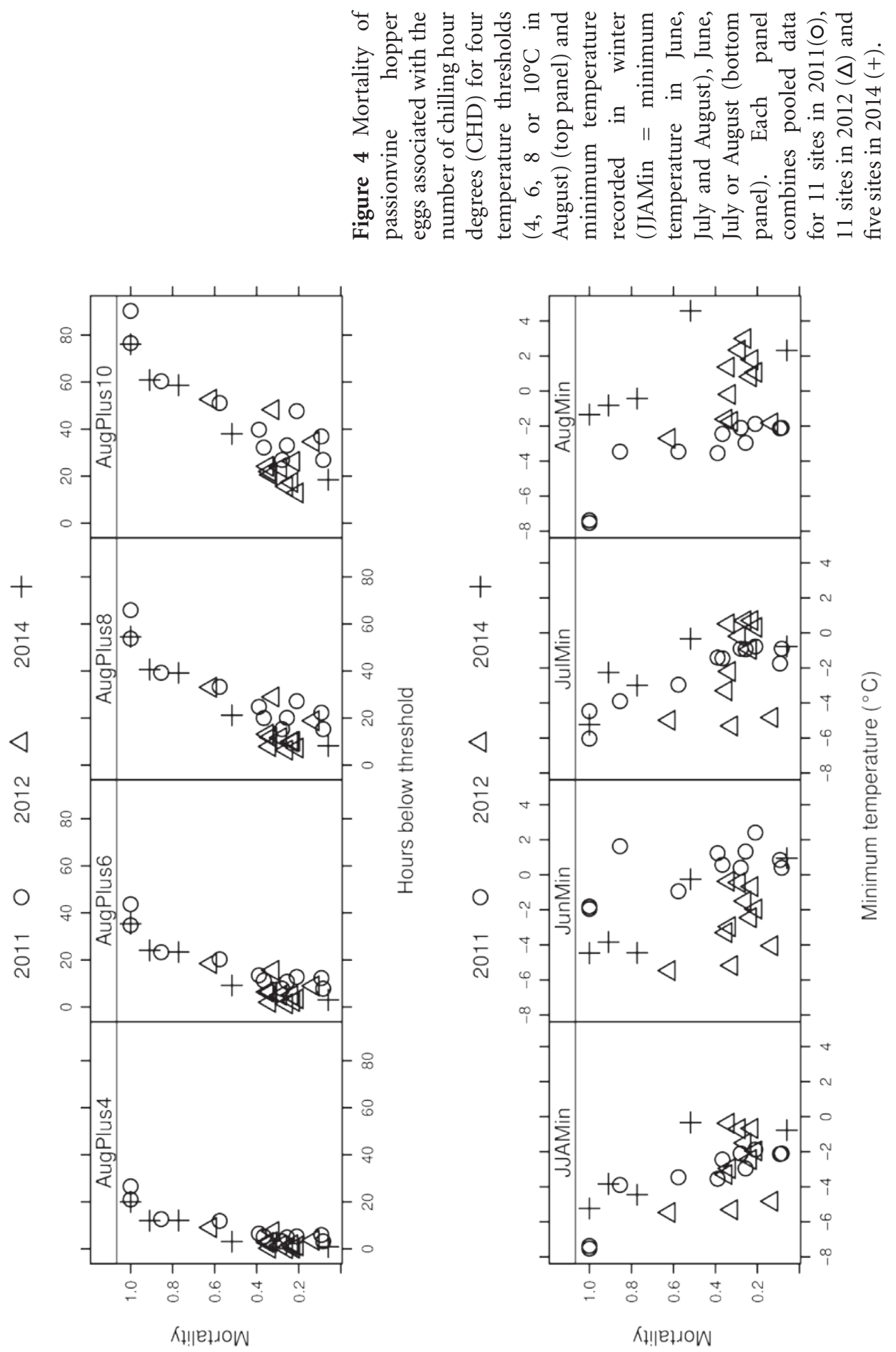


\section{DISCUSSION}

The objective of this research was to assess whether cold temperatures may cause significant mortality of PVH eggs and contribute to annual variation in the abundance of PVH and sooty mould on kiwifruit. Eggs were relatively tolerant of cold shock with a lethal median temperature estimated at $-9.1^{\circ} \mathrm{C}$ for a $1-\mathrm{h}$ exposure and only a mean $61 \%$ mortality at the coldest temperature tested of $-11^{\circ} \mathrm{C}$. This response is consistent with cold-hardiness for other insect species from temperate climates (Turnock \& Fields 2005). For example, mean lethal temperature after a 1-h exposure was $-10.6^{\circ} \mathrm{C}$ to $-6.1^{\circ} \mathrm{C}$ for different stages of the Mediterranean flour moth Ephestia kuehniella (Andreadis et al. 2012). The supercooling point (SCP) when freezing of the fluid in extracellular spaces occurs is often less than $-20^{\circ} \mathrm{C}$ for temperate species (Turnock \& Fields 2005; Chown \& Nicolson 2009). The SCP is frequently measured but is difficult to relate to mortality in the field or to geographic distribution (Renault et al. 2002), which is why it was not measured here. Insects can survive sub-zero temperatures without freezing because of cryoprotectants such as glycerol, sorbitol and antifreeze proteins (Lee Jr 1991). Life-stages in diapause tend to be more tolerant of sub-zero temperatures than those that remain active. Eggs of PVH are probably in diapause between autumn and mid-winter because they have been reported to need chilling and moisture to hatch (Cumber 1966; Matheson 1978), although this was disputed by Fletcher (1978) and also by Gerard (1985).

The variability in mortality response to cold shock was relatively high. The reasons are not clear but may include differences in egg physiology at chilling resulting from the interaction of age, genetic makeup and coldhardening. Cold hardening is a programmed response to declining temperatures and cold shocks that increases tolerance to cold. It is a widespread trait of insect species from temperate and alpine areas (Lee Jr 1991; Chown \& Terblanche 2006). Different pre-treatment conditions are likely to change the cold-shock responses but it is not clear how much change there could be for PVH eggs without further research. In addition, a comparison of substrates (fruit stalk v. balsa wood stick) suggested that this may also influence mortality. Consequently the results reported should here not be generalised without caution.

Mortality would usually be expected to increase with increased exposure time to cold (Turnock \& Fields 2005). In laboratory experiments, egg mortality increased with cooler temperatures but was, at best, weakly associated with exposure period. There was either a modest trend for increased mortality with increased storage time or responses were inconsistent. In one experiment, PVH eggs apparently had lower mortality when the exposure period was doubled. This result was probably due to random variation as a biological explanation is not immediately clear.

In addition to mortality from cold shock, which is expected to occur after short periods (minutes to hours) of chilling (Lee Jr 1991), the longer-term indirect effects of cold temperatures were measured for PVH eggs in different localities. Complete mortality of eggs occurred during winter exposure at some sites on the North Island volcanic plateau consistent with the absence of PVH from that area. The coldest temperatures recorded at these sites $(-5.2$ to $\left.-7.5^{\circ} \mathrm{C}\right)$ were warmer than the median lethal temperature $\left(-9.1^{\circ} \mathrm{C}\right)$ estimated from laboratory studies. When there is no ice formation, mortality due to the direct effects of cold temperatures is thought to be mainly due to the inability to maintain ionic homeostasis leading to failure of the nervous system (MacMillan \& Sinclair 2011). Mechanisms underlying cumulative longer-term effects of chilling are not understood (Chown \& Terblanche 2006; Chown \& Nicolson 2009). In this study, egg mortality during winter was not strongly correlated with minimum temperatures, but was correlated with CHD. The best correlations were with $\mathrm{CHD}$ calculated using August temperatures and at thresholds between 4 and $10^{\circ} \mathrm{C}$. This suggests that, although $\mathrm{PVH}$ eggs can tolerate brief exposure to extremely cold temperatures, they are susceptible to cumulative 
injuries when temperatures consistently stay below $10^{\circ} \mathrm{C}$. The apparently greater susceptibility to cold in August requires further investigation and may be associated with some change in egg physiology.

Air temperatures below $-5^{\circ} \mathrm{C}$ are probably not frequent either on kiwifruit orchards in the Bay of Plenty, the major growing region, or in coastal areas of Nelson, the southern-most growing region. As a consequence, mortality of eggs due to direct chilling is probably not significantly limiting the abundance of PVH in those, and more northern, growing regions. On the other hand, the cumulative effects of indirect chilling injury due to temperatures below $10^{\circ} \mathrm{C}$ may be more important. However, the association of winter egg mortality with the sum of $\mathrm{CHD}$ below $10^{\circ} \mathrm{C}$ in August needs to be validated. This relationship may provide a basis for understanding some of the year to year variation in numbers of $\mathrm{PVH}$, particularly south of the Bay of Plenty where higher chilling hours occur. Further study is necessary to show how indirect chilling injury interacts with other mortality factors such as egg parasitism, failure of neonates to establish at feeding sites and variation in adult fecundity (Cumber 1966; Gerard 1985) to influence the abundance of $\mathrm{PVH}$ populations in production areas.

\section{ACKNOWLEDGEMENTS}

Funding for this study was provided by the Plant \& Food Research Core kiwifruit programme on understanding the risk of sooty mould. We thank Emma Barraclough and Cathy McKenna (Plant \& Food Research), and an anonymous reviewer and the editor for improving the text.

\section{REFERENCES}

Andreadis SS, Eliopoulos PA, SavopoulouSoultani M 2012. Cold hardiness of immature and adult stages of the Mediterranean flour moth, Ephestia kuehniella. Journal of Stored Products Research 48: 132-136.

Andrewartha HG, Birch LC 1984. The Ecological Web: More on the distribution and abundance of animals. University of Chicago, Chicago. $520 \mathrm{p}$.
Bale JS 1996. Insect cold hardiness: a matter of life and death. European Journal of Entomology 93: 369-382.

Chambers JM, Hastie TJ 1992. Statistical models in S. Wadsworth and Brooks/Cole Advanced Books \& Software, Pacific Grove, CA. 608 p.

Charles JG, Allan DJ 2004. Passionvine hopper, Scolypopa australis (Walker) (Hemiptera: Ricaniidae), egg parasitism by Aphelinidae (Hymenoptera) in New Zealand. New Zealand Entomologist 27: 83-89.

Chown SL, Gaston KJ 1999. Exploring the links between physiology and ecology at macroscales: the role of respiratory metabolism in insects. Biological Reviews 74: 87-120.

Chown SL, Terblanche JS 2006. Physiological diversity in insects: Ecological and evolutionary contexts. Advances in Insect Physiology 33: 50-152.

Chown SL, Nicolson SW 2009. Insect physiological ecology: Mechanisms and patterns. Oxford University Press, Oxford. $243 \mathrm{p}$.

Cumber RA 1966. Factors influencing population levels of Scolypopa australis Walker (Hemiptera-Homoptera: Ricaniidae) in New Zealand. New Zealand Journal of Science 9: 336-356.

Cumber RA 1967. Factors influencing egg survival of Scolypopa australis Walker (Hemiptera-Homoptera: Ricaniidae) in the Sydney area (N.S.W. Australia). New Zealand Journal of Science 10: 639-643.

Fletcher MJ 1978. The taxonomy, reproduction and development of the Fulgoroid homopterans Scolypopa australis (Walker) (Ricaniidae) and Kallitambinia australis (Muir) (Tropiduchidae). $\mathrm{PhD}$ thesis, University of Sydney, Sydney. 208 p.

Gerard PJ 1985. The ecology of Scolypopa australis and its parasite Centrodora scolypopae. $\mathrm{PhD}$ thesis, University of Waikato, Hamilton. $257 \mathrm{p}$.

Lee Jr RE 1991. Principles of insect low temperature tolerance. In: Lee Jr RE, Denlinger DL ed. Insects at low temperature. Chapman \& Hall, New York. Pp. 17-47. 
Logan DP, Allison P, Stannard K 2002. Selection of wild hosts for feeding by passion vine hopper, Scolypopa australis (Walker) (Hemiptera: Ricaniidae) in the Bay of Plenty. New Zealand Plant Protection 55: 368-373.

MacMillan HA, Sinclair BJ 2011. Mechanisms underlying insect chill-coma. Journal of Insect Physiology 57: 12-20.

Matheson AG 1978. Aspects of the biology of Scolypopa australis Walker (Homoptera: Ricaniidae). MSc thesis, University of Waikato Hamilton. 122 p.

R Development Core Team 2016. R: A language and environment for statistical computing. R Foundation for Statistical Computing, Vienna, Austria. URL http://www.R-project.org/.

Renault D, Salin C, Vannier G, Vernon P 2002. Survival at low temperatures in insects: what is the ecological significance of the supercooling point? Cryo Letters 23: 217-228.
Riley CV, Howard LO 1891. A New Zealand froghopper. Insect Life 3: 424.

Robertson LM, Edlin JS, Edwards JD 2010. Investigating the importance of altitude and weather condtions for the production of toxic honey in New Zealand. New Zealand Journal of Crop and Horticultural Science 38: 87-100. Spiller DM, Wise KAJ 1982. A catalogue (18601960) of New Zealand insects and their host plants. DSIR Science Information Division, Wellington. $260 \mathrm{p}$.

Steven D 1990. Entomology and kiwifruit. In: Warrington IJ, Weston GC ed. Kiwifruit: Science and Management. Ray Richards Publisher, Auckland. Pp. 362-412.

Turnock WJ, Fields PG 2005. Winter climates and coldhardiness in terrestrial insects. European Journal of Entomology 102: 561-576. 